\title{
Acquired methemoglobinemia in infants
}

Süt çocuklarında edinsel methemoglobinemi

\author{
Mehmet Mutlu, Erol Erduran, Yakup Aslan \\ Department of Pediatrics, Faculty of Medicine, Karadeniz Technical University, Trabzon, Turkey
}

\begin{abstract}
Objective: This study aimed to determine the etiologic factors of acquired methemoglobinemia in infants younger than three months in our region.

Material and Methods: This study was carried out retrospectively in infants with methemoglobinemia admitted to Karadeniz Technical University, Pediatric Clinic, during the period 2000-2009. Infants with methemoglobinemia were identified according to the medical records or ICD-10 code.

Results: Nine infants with acquired methemoglobinemia $(8$ male, 1 female) were included in the study. Seven cases were associated with the use of prilocaine for circumcision, one case with the use of prilocainelidocaine for local pain therapy, and one case with neonatal sepsis caused by Staphylococcus aureus.

Conclusion: Prilocaine should not be used in infants less than three months of age because of the risk of methemoglobinemia. Ascorbic acid is an effective therapy if methylene blue is not obtained. It should not be forgotten that sepsis caused by $\boldsymbol{S}$. aureus may cause methemoglobinemia in infants.

(Turk J Hematol 2011; 28: 131-4)

Key words: Methemoglobinemia, infant, local anesthetics, sepsis
\end{abstract}

Received: April 8, 2010

Accepted: May 11, 2010

\section{Özet}

Amaç: Bölgemizde üç aydan küçük bebeklerde meydana gelen akkiz methemoglobinemilerin etiyolojisini araştırmak.

Yöntem ve Gereçler: Bu çalışma, 2000-2009 yılları arasında pediatri kliniğine başvuran ve ICD-10 koduna veya hasta kayıt defterine göre akkiz methemoglobinemi tanısı alan hastaların kayıtlarının retrospektif incelenmesi ile gerçekleştirildi.

Bulgular: Sekizi erkek olmak üzere, dokuz akkiz methemoglobinemili infant çalışmaya alındı. Yedi vaka; sünnet için prilokain kullanımı ile ilişkili iken, bir vaka; lokal anestezi için kullanılan prilokainlidokain ile ve diğer vaka ise; Staphylococcus aureus sepsisi ile ilişkili idi.

Sonuç: Üç aydan küçük infantlarda prilokain methemoglobinemi riski nedeniyle kullanılmamalıdır ve metilen mavisi elde edilemediği durumlarda vitamin C effektif bir tedavi şeklidir. Staphylococcus aureus'a bağlı sepsisin infantlarda methemoglobinemiye neden olabileceği unutulmamalıdır.

(Turk J Hematol 2011; 28: 131-4)

Anahtar kelimeler: Methemoglobinemi, infant, lokal anestezikler, sepsis

Geliş tarihi: 8 Nisan 2010

Kabul tarihi: 11 Mayıs 2010

Address for Correspondence: Asst. Prof. Mehmet Mutlu, Department of Pediatrics, Faculty of Medicine, Karadeniz Technical University, Trabzon, Turkey Phone: +90 4623775568 E-mail: drmehmetmutlu38@hotmail.com 


\section{Introduction}

Methemoglobinemia is an uncommon cause of cyanosis. It should be suspected in an infant with cyanosis who has no respiratory distress or cyanotic congenital heart disease. Cyanosis is recognized in patients with methemoglobin (MetHb) concentrations higher than $1.5 \mathrm{~g} / \mathrm{dl}[1,2]$. It develops due to both acquired and congenital factors. Congenital causes of methemoglobinemia are NADH-cytochrome b5 reductase and NADPH-MetHb reductase deficiencies or presence of abnormal $\mathrm{Hb}$ such as $\mathrm{Hb} \mathrm{M}$ [2]. Acquired methemoglobinemia is caused by some drugs such as local anesthetics, some foods or water containing high levels of nitrate, gastrointestinal infection, and sepsis [2-4]. Most of the acquired methemoglobinemia cases in clinical practice are due to local anesthetics. In this report, nine infants with methemoglobinemia are presented and the etiologic factors are discussed.

\section{Materials and Methods}

This study was carried out retrospectively in infants with methemoglobinemia admitted to Karadeniz Technical University, Pediatric Clinic, during the period 2000-2009. Infants with methemoglobinemia were identified according to the medical records or ICD-10 code. Medical charts of all infants with methemoglobinemia were reviewed for birth weight (g), gender, postnatal age, $\mathrm{Hb}$ levels, presenting symptoms, etiologic causes, type of feeding, MetHb levels, treatment, recovery time of methemoglobinemia, and glucose6-phosphate dehydrogenase (G6PD) deficiency. Blood MetHb levels were measured by using a Rapidlab® 1200 Blood Gas Analyzer (Siemens Healthcare Diagnostics) with spectrophotometric method. Blood MetHb levels were measured at fourhour intervals. Sepsis was considered in infants having two or more of the following criteria associated with positive blood culture: (a) fever or hypothermia, (b) tachycardia, (c) tachypnea or apnea, and (d) abnormal white blood cells or increase in band/total neutrophils. Written informed consent was obtained from the patients' family.

\section{Results}

Nine infants with methemoglobinemia ( 8 male, 1 female) were included in the study. Mean birth weight and postnatal age were $3655 \pm 270$ (33004100) g and 33.7 $\pm 16.6 \mathrm{~d}$ (5-60) days, respectively. Cyanosis was present in all infants, fever in three (33\%), and hypotonia and refusal to breast-feed in two $(22 \%)$. Mean percentage of MetHb levels of the infants was $28.8 \pm 9.8$ (14.7-44\%). Seven cases were associated with the use of a local anesthetic agent (prilocaine; Citanest ${ }^{\circledR}$ 0.5\%) for circumcision. The applied prilocaine doses were not determined. One case was associated with the use of prilocaine-lidocaine (EMLA ${ }^{\circledR}, 5 \%$, Astra Zeneca) for local pain therapy after scalding to $3 \%$ of the body surface, and three cases were associated with neonatal sepsis. No phenol disinfectant was used for floor cleaning in the hospital during this period.

Staphylococcus hominis was grown in blood cultures of two infants (Case 3 and Case 5) associated with the use of prilocaine. Staphylococcus aureus was grown in the blood culture of Case 6. Acute phase reactants (procalcitonin and C-reactive protein [CRP]) were positive in these neonates, and they met sepsis criteria. They were treated with vancomycin. All of the neonates were receiving only breast milk. Their mothers denied the use of any medications and consumption of any foods containing a high nitrate level.

Two neonates were treated with methylene blue (1-2 $\mathrm{mg} / \mathrm{kg})$ intravenously, and the others were treated with vitamin C (300 mg) intravenously because methylene blue was not obtained. Repeated doses were not necessary. Mean recovery time was 10.2 \pm 3.5 [4-16] hours. The plasma G6PD levels were normal in all neonates. Cytochrome b5 reductase activity could not be measured in the neonates because of the lack of technical facilities. Demographic, clinic and laboratory characteristics of the neonates associated with methemoglobinemia are shown in Table 1.

\section{Discussion}

Methemoglobinemia is characterized by oxidation of the iron in $\mathrm{Hb}$ from a ferrous $(\mathrm{Fe}++)$ to a ferric $(\mathrm{Fe}+++)$ form. Methemoglobinemia occurs in healthy persons but the intraerythrocytic MetHbreducing system maintains its concentration at less than $1 \%$ of the total $\mathrm{Hb}$ [5]. There are two MetHbreducing systems (NADH-cytochrome b5 reductase and NADPH-MetHb reductase) in erythrocytes. Under physiological conditions, NADH-cytochrome 
Table 1. Demographic, clinic and laboratory characteristics of the patients with methemoglobinemia

\begin{tabular}{|c|c|c|c|c|c|c|c|c|c|c|}
\hline & $\begin{array}{c}\text { Birth } \\
\text { Weight (g) }\end{array}$ & $\begin{array}{l}\text { Postnatal } \\
\text { age (day) }\end{array}$ & Gender & Complaints & $\begin{array}{c}\mathrm{Hb} \\
(\mathrm{gr} / \mathrm{dL})\end{array}$ & $\begin{array}{c}\text { MetHb } \\
(\%)\end{array}$ & $\begin{array}{l}\text { Etiologic } \\
\text { causes }\end{array}$ & Treatment & $\begin{array}{c}\text { Recovery } \\
\text { time (h) } \\
\text { (MetHb <5\%) }\end{array}$ & $\begin{array}{c}\text { G6PD } \\
\text { level }\end{array}$ \\
\hline Case 1 & 4000 & 45 & Male & Cyanosis & 10.9 & 24.1 & Prilocaine & 300 mg C vit & 8 & Normal \\
\hline Case 2 & 3700 & 60 & Male & Cyanosis & 11.2 & 39.9 & Prilocaine & $300 \mathrm{mg} \mathrm{C}$ vit & 12 & Normal \\
\hline Case 3 & 4100 & 5 & Male & $\begin{array}{l}\text { Cyanosis, hypotonia, } \\
\text { fever, refusal to } \\
\text { breast-feed }\end{array}$ & 14.7 & 14.7 & $\begin{array}{c}\text { Prilocaine } \\
\text { Sepsis } \\
\text { caused by } \\
\text { S. hominis?? }\end{array}$ & $\begin{array}{l}300 \text { mg C vit } \\
\text { +Antibiotics }\end{array}$ & $\begin{array}{l}4 \\
1\end{array}$ & Normal \\
\hline Case 4 & 3300 & 22 & Male & Cyanosis & 8.8 & 33.7 & Prilocaine & 300 mg C vit & 12 & Normal \\
\hline Case 5 & 3600 & 35 & Male & $\begin{array}{c}\text { Cyanosis, fever, } \\
\text { refusal to } \\
\text { breast-feed }\end{array}$ & 13.5 & 19.0 & $\begin{array}{l}\text { Prilocaine- } \\
\text { lidocaine } \\
\text { Sepsis } \\
\text { caused by } \\
\text { S. hominis?? }\end{array}$ & $\begin{array}{l}300 \mathrm{mg} \mathrm{C} \text { vit } \\
\text { +Antibiotics }\end{array}$ & 8 & Normal \\
\hline Case 6 & 3300 & 17 & Female & $\begin{array}{l}\text { Fever, hypotonia, } \\
\text { cyanosis }\end{array}$ & 13.5 & 20.9 & $\begin{array}{l}\text { Sepsis } \\
\text { caused by } \\
\text { S. aureus }\end{array}$ & $\begin{array}{l}300 \text { mg C vit } \\
\text { +Antibiotics }\end{array}$ & 8 & Normal \\
\hline Case 7 & 3600 & 45 & Male & Cyanosis & 10.5 & 44 & Prilocaine & $\begin{array}{c}\text { Methylene } \\
\text { blue }(1 \mathrm{mg} / \mathrm{kg})\end{array}$ & 16 & Normal \\
\hline Case 8 & 3700 & 37 & Male & Cyanosis & 11.5 & 30.4 & Prilocaine & 300 mg C vit & 12 & Normal \\
\hline Case 9 & 3600 & 48 & Male & Cyanosis & 11.8 & 26.8 & Prilocaine & $\begin{array}{c}\text { Methylene } \\
\text { blue }(1 \mathrm{mg} / \mathrm{kg})\end{array}$ & 12 & Normal \\
\hline
\end{tabular}

G6PD: Glucose-6-phosphate dehydrogenase, Hb: Hemoglobin, MetHb: Methemoglobin

b5 reductase is responsible for the removal of 95-99\% of the MetHb [5]. NADPH-MetHb reductase usually plays only a minor role in the removal of MetHb. This enzyme system utilizes NADPH, which is produced by G6PD. NADPH-MetHb reductase has a more important role in MetHb regulation in infants with cytochrome b5 reductase deficiency. MetHb has an increased affinity for oxygen, and causes a leftward shift in the oxygen dissociation curve, and hypoxemia and lactic acidosis develop [1,2,6]. If MetHb level is higher than $10 \%$, cyanosis occurs, and a MetHb level of $70 \%$ is lethal. Cyanosis was observed in all of our infants and all of them improved after the appropriate treatments.

Prilocaine is widely used in children and adults as a local anesthetic agent, and its metabolite o-toluidine can cause methemoglobinemia. The dose of prilocaine and the age of the infant are the most important predictive factors for higher MetHb formation [7]. Infants are more vulnerable to methemoglobinemia because they have higher gastric $\mathrm{pH}$ than that in older children, and this causes greater bacterial proliferation of the intestinal flora that can convert the ingested nitrate to nitrite [6]. Fetal $\mathrm{Hb}$ is the predominant form of $\mathrm{Hb}$ in infants, and is oxidized more readily to MetHb by nitrite [6]. The cytochrome b5 MetHb reductase activity is reduced $50 \%$ in infants compared with older children and adults [6,8]. Guay [9] suggested that prilocaine should not be used in children younger than six months and the doses should not exceed 2.5 $\mathrm{mg} / \mathrm{kg}$ in children older than six months. In this study, MetHb in seven neonates was associated with the use of prilocaine for circumcision, and all of them were younger than two months.

Symptomatic methemoglobinemia may develop due to the application of EMLA ${ }^{\circledR}$ on the injured skin [10]. Methemoglobinemia was observed in Case 5 due to the application of EMLA ${ }^{\circledR}$ for local pain therapy.

Blood MetHb levels may be increased in patients with sepsis [3,4]. Large amounts of nitric oxide (NO) are released in sepsis and septic shock $[11,12]$. NO interacts with $\mathrm{Hb}$, and leads to methemoglobinemia [13]. S. aureus has a respiratory type of nitrate reductase enzyme system. This enzyme system may convert nitrate to nitrite, and methemoglobinemia may develop [14]. Vancomycin-related methemoglobinemia has not been reported in the literature. We believe that methemoglobinemia was related with sepsis rather than vancomycin [15]; 
nevertheless, methemoglobinemia related with vancomycin could not be completely ruled out. As far as we know, $S$. hominis does not have this enzyme system. Therefore, we believe that prilocaine was responsible for the methemoglobinemia in the neonates (Case 3-Case 5).

Methylene blue accelerates the NADPHdependent MetHb reduction pathway [16]. Methylene blue was given $(1-2 \mathrm{mg} / \mathrm{kg}$ ) in only two infants because it was not obtained for the others. Ascorbic acid directly reduces MetHb and it is effective when used alone [17]. Intravenous $300 \mathrm{mg}$ ascorbic acid was used in seven cases, and all cases recovered between 8-16 hours.

Prilocaine should not be used in infants less than three months of age because of the risk of methemoglobinemia. Ascorbic acid is an effective therapy if methylene blue is not obtained. It should not be forgotten that $S$. aureus may cause methemoglobinemia in infants.

\section{Conflict of interest statement}

The authors of this paper have no conflicts of interest, including specific financial interests, relationships, and/or affiliations relevant to the subject matter or materials included.

\section{References}

1. Ash-Bernal R, Wise R, Wright SM. Acquired methemoglobinemia: a retrospective series of 138 cases at 2 teaching hospitals. Medicine (Baltimore) 2004;83:265-73. [CrossRef]

2. moglobinemia: a rare cause of cyanosis in the newborna case report. Pediatrics 2003;112:e158-61.

3. Ohashi K, Yukioka H, Hayashi M, Asada A. Elevated methemoglobin in patients with sepsis. Acta Anaesthesiol Scand 1998;42:713-6. [CrossRef]

4. May RB. An infant with sepsis and methemoglobinemia. J Emerg Med 1985;3:261-4.
5. Mansouri A, Lurie AA. Concise review: methemoglobinemia. Am J Hematol 1993;42:7-12. [CrossRef]

6. Greer FR, Shannon M. American Academy of Pediatrics Committee on Nutrition; American Academy of Pediatrics Committee on Environmental Health. Infant methemoglobinemia: the role of dietary nitrate in food and water. Pediatrics 2005;116:784-6. [CrossRef]

7. Vasters FG, Eberhart LH, Koch T, Kranke P, Wulf H, Morin AM. Risk factors for prilocaine-induced methaemoglobinaemia following peripheral regional anaesthesia. Eur J Anaesthesiol 2006;23:760-5. [CrossRef]

8. Panin G, Pernechele M, Giurioli R, Secchieri S, Milanesi O, Pellegrino PA, Chiandetti L. Cytochrome b5 reductase activity in erythrocytes and leukocytes as related to sex and age. Clin Chem 1984;30:701-3.

9. Guay J. Methemoglobinemia related to local anesthetics: a summary of 242 episodes Anesth Analg 2009;108:837-45. [CrossRef]

10. Book A, Fehlandt C, Krija M, Radke M, Pappert D. Methemoglobin intoxication by prilocaine in EMLA. Accidental intoxication of an infant with scald injuries. Anaesthesist 2009;58:370-4. [CrossRef]

11. Ochoa JB, Udekwu AO, Billiar TR, Curran RD, Cerra FB, Simmons RL, Peitzman AB. Nitrogen oxide levels in patients after trauma and during sepsis. Ann Surg 1991;214:621-6. [CrossRef]

12. Lorente JA, Delgado MA, Landín L. Septic shock and nitric oxide. Enferm Infecc Microbiol Clin 1997;3:14-9.

13. Wennmalm A, Benthin G, Petersson AS. Dependence of the metabolism of nitric oxide (NO) in healthy human whole blood on the oxygenation of its red cell haemoglobin. Br J Pharmacol 1992;106:507-8.

14. Burke KA, Lascelles J. Nitrate reductase activity in hemedeficient mutants of Staphylococcus aureus. J Bacteriol 1976;126:225-31.

15. Mutlu M, ErduranE,AksoyA, AslanY. Methemoglobinemia associated with Staphylococcus aureus sepsis in a newborn. JNPM 2010;3:63-5.

16. Hoffman R, Benz E, Shattil S, Furie B, Cohen $\mathrm{H}$. Hematology Basic Principles and Practice. New York: Churchill Livingstone, 2005;650-7.

17. Gibson $\mathrm{QH}$. The reduction of methemoglobin by ascorbic acid. Biochem J 1943;37:615-8. 